\title{
Review of Literature for Inputs to the National Water Savings Model and Spreadsheet Tool-Commercial/Institutional
}

Camilla Dunham Whitehead, James D. Lutz, and Moya Melody

\author{
Water and Energy Technology Team \\ Energy Analysis Program \\ Energy and Environment Division \\ Lawrence Berkeley National Laboratory \\ Berkeley CA 94720
}

May 2009

The work described in this paper was supported by the Office of Energy Efficiency and Alternative Fuels Policy, Office of Policy of the U.S. Department of Energy under Contract Number DE-AC02-05CH11231. 


\begin{abstract}
Lawrence Berkeley National Laboratory (LBNL) is developing a computer model and spreadsheet tool for the United States Environmental Protection Agency (EPA) to help estimate the water savings attributable to their WaterSense program. WaterSense has developed a labeling program for three types of plumbing fixtures commonly used in commercial and institutional settings: flushometer valve toilets, urinals, and pre-rinse spray valves. This National Water Savings-Commercial/Institutional (NWS-CI) model is patterned after the National Water Savings-Residential model, which was completed in 2008. Calculating the quantity of water and money saved through the WaterSense labeling program requires three primary inputs: (1) the quantity of a given product in use; (2) the frequency with which units of the product are replaced or are installed in new construction; and (3) the number of times or the duration the product is used in various settings.

To obtain the information required for developing the NWS-CI model, LBNL reviewed various resources pertaining to the three WaterSense-labeled commercial/institutional products. The data gathered ranged from the number of commercial buildings in the United States to numbers of employees in various sectors of the economy and plumbing codes for commercial buildings. This document summarizes information obtained about the three products' attributes, quantities, and use in commercial and institutional settings that is needed to estimate how much water EPA's WaterSense program saves.
\end{abstract}




\section{REVIEW OF LITERATURE FOR INPUTS TO THE NATIONAL WATER SAVINGS MODEL AND SPREADSHEET TOOL-COMMERCIAL/INSTITUTIONAL}

\section{TABLE OF CONTENTS}

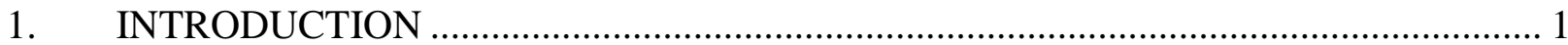

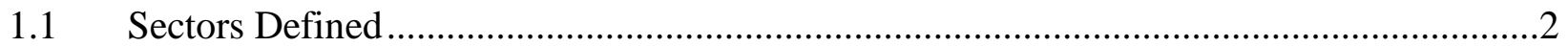

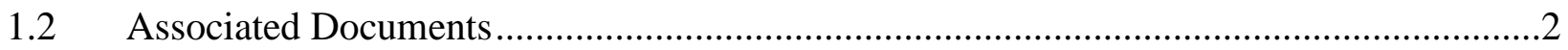

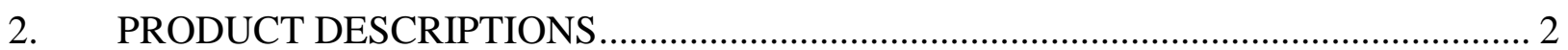

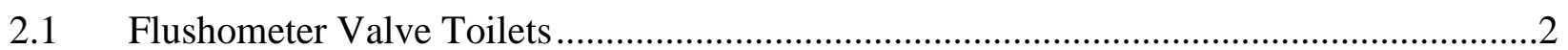

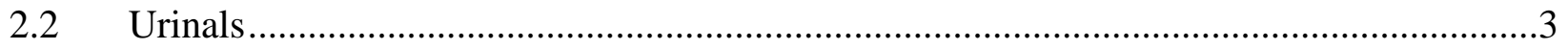

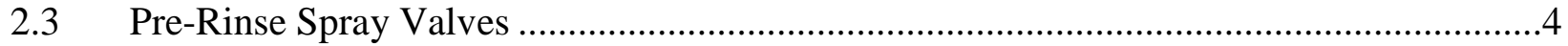

3. TYPES OF COMMERCIAL/INSTITUTIONAL BUILDINGS ……………….............. 5

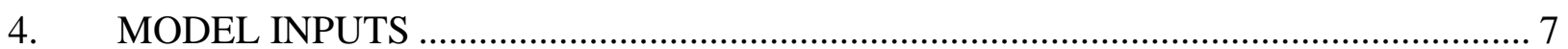

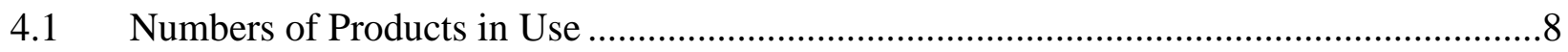

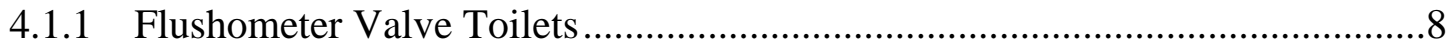

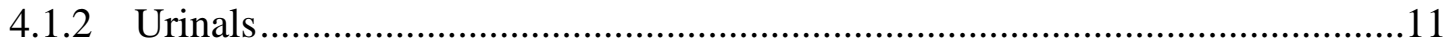

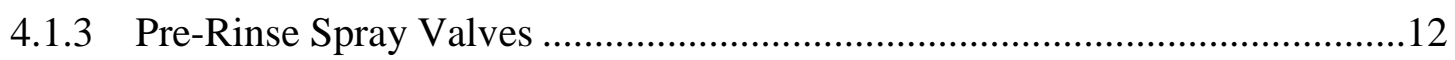

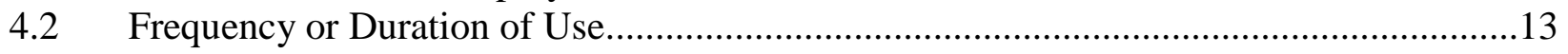

4.2.2 Flushometer Valve Toilets .......................................................................14

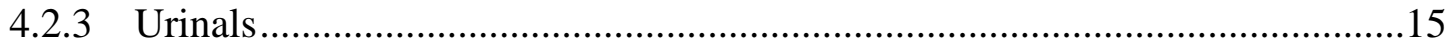

4.2.4 Pre-rinse Spray Valves..........................................................................16

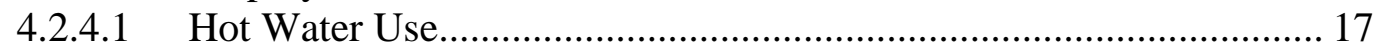

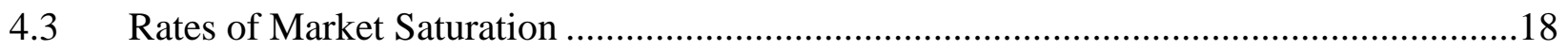

4.3.1 Product Lifetimes....................................................................................18

4.3.2 Product Replacement Rates .......................................................................18

4.3.3 Rate of New Construction......................................................................19

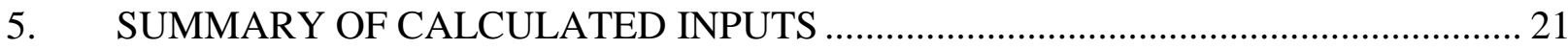

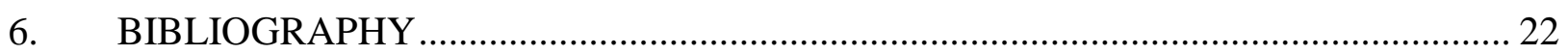

\section{LIST OF TABLES}

Table 3.1 Building Types Sampled by Commercial and Business Energy

Consumption Surveys ..................................................................................

Table 4.1 Numbers of Buildings (thousands) in Various Commercial and Institutional Enterprises (EIA, 2003 CBECS) .....................................................

Table 4.2 U.S. Shipments and Imports of Toilets (Catalina Research, 2007) ........................10

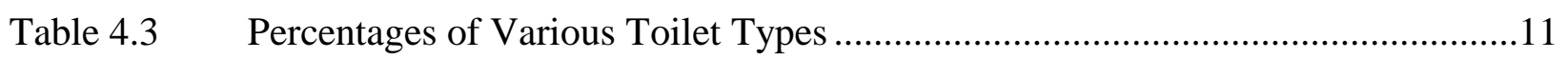

Table 4.4 U.S. Shipments and Imports of Urinals (Catalina Research, 2007)........................12 
Table 4.5 Pre-Rinse Spray Valves by Building Type ................................................... 12

Table 4.6 Parameters for Frequency of Use by Building Type .......................................14

Table $4.7 \quad$ Frequency of Toilet Flushing in Nonresidential Settings .................................15

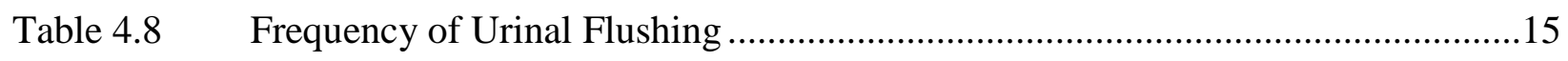

Table 4.9 Frequency of Urinal Flushing in Nonresidential Settings..................................16

Table 4.10 Duration of Pre-Rinse Spray Valve Use (hours/day) in Nonresidential

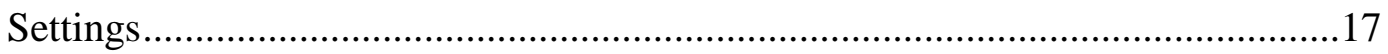

Table 4.11 Water Temperatures for Pre-Rinse Spray Valves (Tso and Koeller, 2005; SBW Consulting, 2007) ..................................................................................... 18

Table 4.12 Lifetimes of Commercial Products (years) by Study........................................18

Table 4.13 Forecast of Nonresidential Floorspace (billion square feet) (EIA, 2009

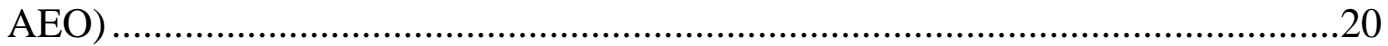

Table 4.14 Recent and Predicted National Employment (U.S. BLS, 2007) .........................21

Table 5.1 Summary of Data Used as Inputs to Model ....................................................22

\section{LIST OF FIGURES}

Figure 2.1 Schematic of Flushometer Valve Toilet (Sloan Flushometer-Royal 100)..............3

Figure 2.2 Schematic of Urinal (Toto-Kiki)...................................................................... 3

Figure 2.3 Schematic of Pre-Rinse Spray Valve (Chicago Faucets) ....................................4

Figure 4.1 Numbers of Buildings by Type and CBECS Year............................................10

Figure 4.2 Forecast of Surviving and New Construction of Commercial Floorspace in the United States (EIA, 2009 AEO) .............................................................19 


\section{REVIEW OF LITERATURE FOR INPUTS TO THE NATIONAL WATER SAVINGS MODEL AND SPREADSHEET TOOL- COMMERCIAL/INSTITUTIONAL}

\section{INTRODUCTION}

The United States Environmental Protection Agency (EPA) established the WaterSense program to reduce national water use by promoting water efficient products and practices. By affixing its label to water efficient products, WaterSense helps inform consumers' decisions about product purchases. In addition to identifying products for its indoor residential labeling program, WaterSense identified three commercial/institutional products to evaluate for labeling: flushometer valve toilets, urinals, and pre-rinse spray valves.

Lawrence Berkeley National Laboratory (LBNL) is developing a computer model and spreadsheet tool to help estimate the water savings attributable to the WaterSense commercial/institutional labeling program. This National Water SavingsCommercial/Institutional (NWS-CI) model is patterned after the National Water SavingsResidential model, which was completed in 2008. Calculating the quantity of water and money saved through the WaterSense labeling program requires three primary inputs: (1) the quantity of a given product in use; (2) the frequency with which units of the product are replaced" or installed in new construction; and (3) the number of times or the duration a product is used in various settings. A building used for public assembly, for example, may experience a frequency of use different from that of a school.

To obtain the information required for developing the NWS-CI model, LBNL reviewed various resources pertaining to the three WaterSense-labeled commercial/institutional products. The data gathered ranged from the number of commercial buildings in the United States to numbers of employees in various sectors of the economy and plumbing code requirements for commercial buildings. This document summarizes information obtained about the three products' attributes, quantities, and use in commercial and institutional settings that is needed to estimate how much water EPA's WaterSense program saves.

\footnotetext{
${ }^{*}$ Replacement in this case occurs at the end of a product's lifetime or during a remodel.
} 


\subsection{Sectors Defined}

The NWS-CI model includes information on product use in the commercial and institutional sectors. The commercial sector, which provides or distributes products or services, encompasses hotels, restaurants, office buildings, commercial businesses, or other places of commerce. Not included within this sector are multi-family residences or agricultural or industrial enterprises. The institutional sector comprises public service, including schools, courts, churches, hospitals, and government institutions regardless of ownership [California Urban Water Conservation Council (CUWCC), 2008].

\subsection{Associated Documents}

This document describes the data, sources of data, and approach to analyzing data that LBNL used to develop inputs to the NWS-CI model. The analytical methods used to determine the numbers of toilets, urinals, and pre-rinse spray valves in use and to calculate the water and financial savings attributable to the WaterSense labeling program are described in the methodology report for the model. LBNL also developed a spreadsheet tool and a user's guide for performing model calculations..$^{\dagger}$

\section{PRODUCT DESCRIPTIONS}

This section describes the three products that WaterSense is including in its commercial/institutional labeling program: flushometer valve toilets, urinals, and pre-rinse spray valves.

\subsection{Flushometer Valve Toilets}

Toilets that utilize flushometer valves usually are found in commercial or institutional settings where high public use is expected. Instead of having a water tank, as gravity flush and pressureassisted toilets do, flushometer valve toilets employ a standpipe located behind the toilet seat; the flush valve is located inside the top of the pipe. The flushing mechanism utilizes water pressure from the supply line to remove waste. The toilets are ruggedly built and have a shorter recovery time than do gravity flush or pressure-assisted toilets. Figure 2.1 shows a schematic of a flushometer valve toilet.

\footnotetext{
${ }^{\dagger}$ The spreadsheet tool, guide, and methodology report are scheduled for release in late 2009.
} 


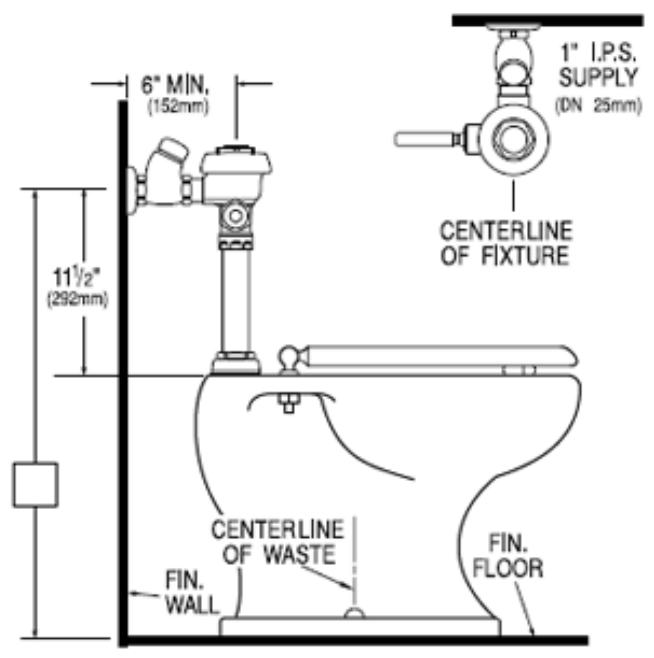

Figure 2.1 Schematic of Flushometer Valve Toilet (Sloan FlushometerRoyal 100)

\subsection{Urinals}

A urinal is a receptacle for collecting and disposing of urine produced by men. The use of urinals minimizes the amount of space and time required for operation: urinals are installed without the enclosures that generally are placed around toilets, and urinals do not require maneuvering a seat. Figure 2.2 shows a schematic of a typical urinal.

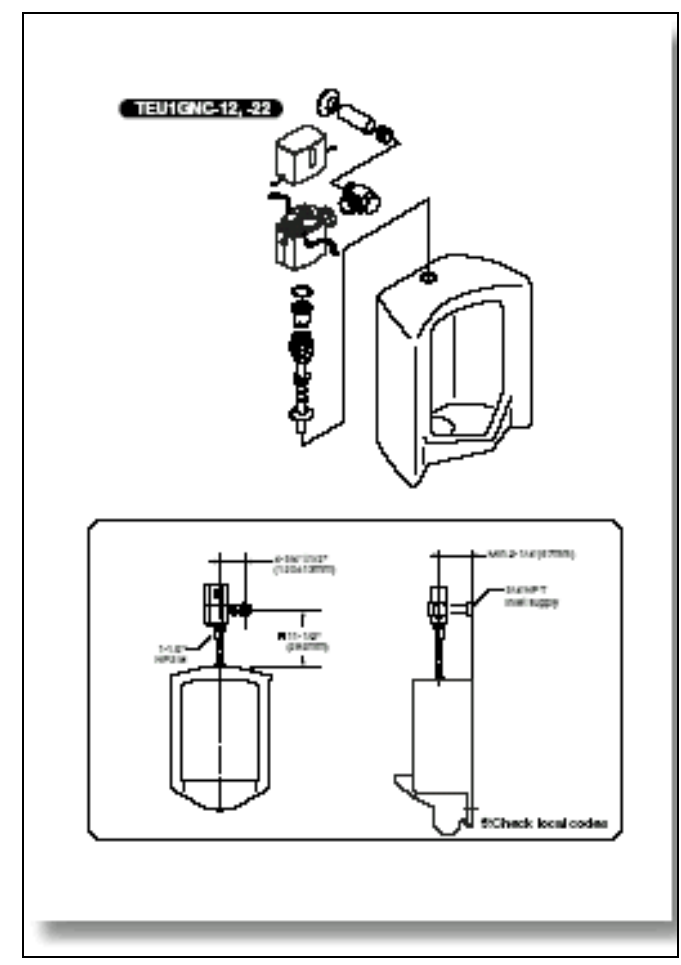

Figure 2.2 Schematic of Urinal (Toto-Kiki) 


\subsection{Pre-Rinse Spray Valves}

Used primarily in commercial kitchens, pre-rinse spray valves produce a spray of water that removes food waste from dishes before they are loaded into a dishwasher. Pre-rinsing kitchen and dish ware not only consumes water, but also the energy used to heat the water. Pre-rinsing also contributes to wastewater (sewer) charges. Pre-rinse spray valves that produce high-velocity spray patterns not only save water and energy, but also clean substantially better than those that simply use a flow restrictor to achieve a recommended flow rate [Federal Energy Management Program (FEMP), 2008]. Figure 2.3 shows a schematic of a pre-rinse spray valve.

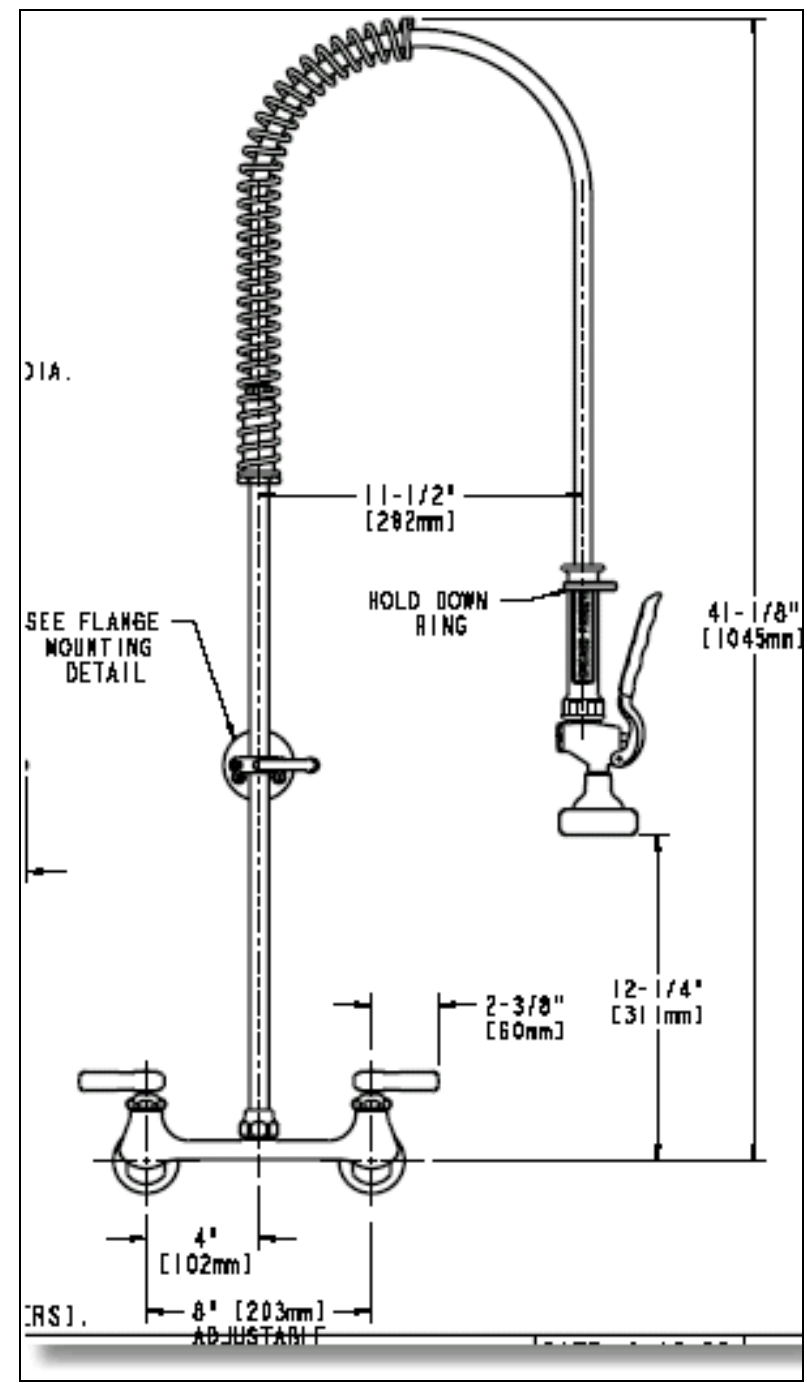

Figure 2.3 Schematic of Pre-Rinse Spray Valve (Chicago Faucets) 


\section{TYPES OF COMMERCIAL/INSTITUTIONAL BUILDINGS}

The Energy Information Administration (EIA), which is part of the U.S. Department of Energy, performs a Commercial and Business Energy Consumption Survey ${ }^{\ddagger}$ (CBECS) that samples 13 types of buildings. Table 3.1 defines and describes 13 CBECS-designated building types.

\section{Table 3.1 Building Types Sampled by Commercial and Business Energy Consumption Surveys}

\begin{tabular}{|c|c|c|}
\hline $\begin{array}{l}\text { Building } \\
\text { Type }\end{array}$ & Definition & $\begin{array}{l}\text { Includes the Following } \\
\text { Subcategories (based on } \\
2003 \text { questionnaire) }\end{array}$ \\
\hline Education & $\begin{array}{l}\text { Buildings used for academic or technical instruction, } \\
\text { such as elementary, middle, or high schools, and } \\
\text { classroom buildings on college or university campuses. } \\
\text { Campus buildings for which the primary use is not } \\
\text { classroom fall into whatever category relates to their } \\
\text { use. For example, administration buildings are part of } \\
\text { "Office," dormitories are "Lodging," and libraries are } \\
\text { "Public Assembly." }\end{array}$ & $\begin{array}{l}\text { Elementary, middle, or high } \\
\quad \text { school } \\
\text { College or university } \\
\text { Preschool or daycare } \\
\text { Adult education } \\
\text { Career or vocational training } \\
\text { Religious education }\end{array}$ \\
\hline Food Sales & Buildings used for retail sale or wholesale of food. & $\begin{array}{l}\text { Grocery store or food market } \\
\text { Gas station with convenience } \\
\text { store } \\
\text { Convenience store }\end{array}$ \\
\hline Food Service & $\begin{array}{l}\text { Buildings used for the preparation and sale of food and } \\
\text { beverages for consumption. }\end{array}$ & $\begin{array}{l}\text { Fast-food outlet } \\
\text { Restaurant or cafeteria }\end{array}$ \\
\hline $\begin{array}{l}\text { Health Care } \\
\text { (Inpatient) }\end{array}$ & $\begin{array}{l}\text { Buildings used as diagnostic and treatment facilities for } \\
\text { inpatient care. }\end{array}$ & $\begin{array}{l}\text { Hospital } \\
\text { Inpatient rehabilitation }\end{array}$ \\
\hline $\begin{array}{l}\text { Health Care } \\
\text { (Outpatient) }\end{array}$ & $\begin{array}{l}\text { Buildings used as diagnostic and treatment facilities for } \\
\text { outpatient care. Medical offices are included if they use } \\
\text { any type of diagnostic medical equipment. If they do } \\
\text { not, they are categorized as office buildings. }\end{array}$ & $\begin{array}{l}\text { Medical office (see previous } \\
\text { column) } \\
\text { Clinic or other outpatient health } \\
\text { care } \\
\text { Outpatient rehabilitation } \\
\text { Veterinarian }\end{array}$ \\
\hline
\end{tabular}

${ }^{\dagger}$ CBECS, a national survey of U.S. commercial buildings, collects information such as building characteristics, number of occupants, and primary building uses. The first CBECS was conducted in 1979; the most recent in 2003. Currently, EIA performs a CBECS every four years. Their survey sample of 5,215 buildings is weighted to represent a total of 4,859,000 commercial buildings (http://www.eia.doe.gov/emeu/cbecs/). 


\begin{tabular}{|c|c|c|}
\hline $\begin{array}{l}\text { Building } \\
\text { Type }\end{array}$ & Definition & $\begin{array}{l}\text { Includes the Following } \\
\text { Subcategories (based on } \\
2003 \text { questionnaire) } \\
\end{array}$ \\
\hline Lodging & $\begin{array}{l}\text { Buildings that provide multiple accommodations for } \\
\text { short- or long-term residents, including skilled nursing } \\
\text { facilities and other residential care buildings. }\end{array}$ & $\begin{array}{l}\text { Motel, hotel, or inn } \\
\text { Dormitory, fraternity, or sorority } \\
\text { Retirement home } \\
\text { Residential care (nursing home, } \\
\quad \text { assisted living) } \\
\text { Convent or monastery } \\
\text { Shelter, orphanage, or children's } \\
\quad \text { home } \\
\text { Halfway house }\end{array}$ \\
\hline $\begin{array}{l}\text { Mercantile } \\
\text { (Retail other } \\
\text { than Mall) }\end{array}$ & $\begin{array}{l}\text { Buildings used for the sale and display of goods other } \\
\text { than food. }\end{array}$ & $\begin{array}{l}\text { Retail store } \\
\text { Beer, wine, or liquor store } \\
\text { Rental center } \\
\text { Dealership or showroom for } \\
\quad \text { vehicles or boats } \\
\text { Studio/gallery }\end{array}$ \\
\hline $\begin{array}{l}\text { Mercantile } \\
\text { (Mall) }\end{array}$ & $\begin{array}{l}\text { Shopping malls composed of multiple connected } \\
\text { establishments. }\end{array}$ & $\begin{array}{l}\text { Enclosed mall } \\
\text { Strip mall }\end{array}$ \\
\hline Office & $\begin{array}{l}\text { Buildings used for general office space, professional } \\
\text { offices, or administrative offices. Medical offices are } \\
\text { included if they do not use any type of diagnostic } \\
\text { medical equipment. If they do, they are categorized as } \\
\text { Health Care (Outpatient). }\end{array}$ & $\begin{array}{l}\text { Administrative or professional } \\
\text { office } \\
\text { Government office } \\
\text { Mixed-use office } \\
\text { Bank or other financial } \\
\quad \text { institution } \\
\text { Medical office (see previous } \\
\text { column) } \\
\text { Sales office } \\
\text { Contractor's office (e.g., } \\
\quad \text { construction, plumbing) } \\
\text { Non-profit or social services } \\
\text { Research and development } \\
\text { City hall or city center } \\
\text { Religious office } \\
\text { Call center }\end{array}$ \\
\hline
\end{tabular}




\begin{tabular}{|c|c|c|}
\hline $\begin{array}{c}\text { Building } \\
\text { Type }\end{array}$ & Definition & $\begin{array}{l}\text { Includes the Following } \\
\text { Subcategories (based on } \\
2003 \text { questionnaire) }\end{array}$ \\
\hline $\begin{array}{l}\text { Public } \\
\text { Assembly }\end{array}$ & $\begin{array}{l}\text { Buildings in which people gather for social or } \\
\text { recreational activities, whether in private or public } \\
\text { facilities. }\end{array}$ & $\begin{array}{l}\text { Social or meeting place (e.g., } \\
\text { community center, lodge, } \\
\text { convention center, senior } \\
\text { center) } \\
\text { Recreational facility (e.g., health } \\
\text { club, gymnasium, bowling } \\
\text { alley, ice rink, indoor sports) } \\
\text { Entertainment or culture (e.g., } \\
\text { museum, theater, sports } \\
\text { arena, night club) } \\
\text { Library } \\
\text { Funeral home } \\
\text { Student activities center } \\
\text { Armory } \\
\text { Exhibition hall } \\
\text { Broadcasting studio } \\
\text { Transportation terminal }\end{array}$ \\
\hline $\begin{array}{l}\text { Public Order } \\
\text { and Safety }\end{array}$ & $\begin{array}{l}\text { Buildings used for the preservation of law and order or } \\
\text { public safety. }\end{array}$ & $\begin{array}{l}\text { Police station } \\
\text { Fire station } \\
\text { Jail, reformatory, or penitentiary } \\
\text { Courthouse or probation office }\end{array}$ \\
\hline $\begin{array}{l}\text { Religious } \\
\text { Worship }\end{array}$ & $\begin{array}{l}\text { Buildings used for religious gatherings and activities, } \\
\text { such as chapels, churches, mosques, synagogues, and } \\
\text { temples. }\end{array}$ & No subcategories identified \\
\hline Service & $\begin{array}{l}\text { Buildings in which some type of service, other than } \\
\text { food service or retail sales of goods, is provided. }\end{array}$ & $\begin{array}{l}\text { Vehicle service/repair shop } \\
\text { Vehicle storage or maintenance } \\
\quad \text { (car barn) } \\
\text { Repair shop } \\
\text { Dry cleaner or laundromat } \\
\text { Post office or postal center } \\
\text { Car wash } \\
\text { Gas station } \\
\text { Photo-processing shop } \\
\text { Beauty parlor or barber shop } \\
\text { Tanning salon } \\
\text { Copy center or printing shop } \\
\text { Kennel }\end{array}$ \\
\hline
\end{tabular}

\section{MODEL INPUTS}

Water savings are calculated by subtracting the water consumption of a product that has a lower flow rate from the consumption of the same type of product having a higher flow rate, then multiplying that difference by the number of products in question and the number of times the 
product type is used. Another input to the savings calculation is the percentage of WaterSense products that would be purchased in the absence of the program, because those savings must be subtracted from the savings attributable to WaterSense. The estimates developed for that input are described in the methodology report for the National Water SavingsCommercial/Institutional (NWS-CI) model. Section 4.1 of this literature review summarizes how we estimate the number of flushometer valve toilets, urinals, and pre-rinse spray valves in use. In section 4.2 we approximate frequency or duration of use, and in section 4.3 predict rates of market saturation based on the spectrum of how long current products have been installed and how much commercial floorspace is being constructed.

\subsection{Numbers of Products in Use}

The number of each type of product in use is input to the NWS-CI model as the baseline number, which is needed to estimate the success of the WaterSense labeling program. This section summarizes findings from the literature regarding the numbers of flushometer valve toilets, urinals, and pre-rinse spray valves in use. The methodology used to estimate the numbers of toilets and urinals is described in detail in the separate methodology report.

\subsubsection{Flushometer Valve Toilets}

The literature indicates that flushometer valve (FV) toilets were developed in the early 1900s (http://www.plumbingsupply.com/pmtoilet.html) to serve settings that are subject to heavy use so that a fast reuse rate is important; a minimal drop in water pressure within the plumbing system is desired; and heavy mixed media loads are expected. Because FV toilets also are highly durable, they are used in places such as travel centers (bus depots, train stations, airports); hotel lobbies; stadiums; and educational facilities (schools, universities). The number of FV toilets must be estimated for modeling purposes, because no national survey has recorded their number or replacement rate. Adding to the modeling challenge, FV toilets are only one among several types of toilets installed in commercial/institutional settings (the others being gravity flush and pressure-assisted). This section describes how we estimate the number of FV toilets in commercial/institutional settings for input to the NWS-CI model.

To estimate the number of FV toilets per person in commercial and institutional buildings, we gathered information for calculating the total number of all types of toilets per person. To establish minimum numbers of toilets in various building types, we used the International Association of Plumbing and Mechanical Officials' (IAMPO's) Uniform Plumbing Code (UPC; 
IAMPO, 2005). ${ }^{\S}$ The UPC designates the minimum number of toilets required for a nonresidential building as a function of the number of employees and visitors.

To estimate the number of people per building type, we used the Energy Information Administration's (EIA's) Commercial and Business Energy Consumption Surveys (CBECSs). From the CBECS, which provides more current information than does the U.S. Census Bureau, the EIA estimates the numbers of various types of commercial and institutional buildings in the nation. Table 4.1 shows the data derived from the CBECSs for the 11 enterprise categories that are considered in the NWS-CI model.

Table 4.1 Numbers of Buildings (thousands) in Various Commercial and Institutional Enterprises (EIA, 2003 CBECS)

\begin{tabular}{|c|c|c|c|c|c|c|c|c|c|c|c|}
\hline $\begin{array}{c}\text { CBECS } \\
\text { Year }\end{array}$ & Education & $\begin{array}{c}\text { Food } \\
\text { Sales }\end{array}$ & $\begin{array}{c}\text { Food } \\
\text { Service }\end{array}$ & $\begin{array}{c}\text { Health } \\
\text { Care }\end{array}$ & Lodging & Retail & Office & $\begin{array}{c}\text { Public } \\
\text { Assembly }\end{array}$ & $\begin{array}{c}\text { Public } \\
\text { Order } \\
\text { \& } \\
\text { Safety }\end{array}$ & $\begin{array}{c}\text { Religious } \\
\text { Worship }\end{array}$ & Service \\
\hline 1992 & 301 & 130 & 260 & 63 & 154 & 1,272 & 749 & 278 & 60 & 366 & Q \\
\hline 1995 & 309 & 137 & 285 & 105 & 158 & 1,289 & 705 & 326 & 87 & 269 & Q \\
\hline 1999 & 327 & 174 & 349 & 127 & 153 & 667 & 739 & 305 & 72 & 307 & 478 \\
\hline 2003 & 386 & 226 & 297 & 129 & 142 & 657 & 824 & 277 & 71 & 370 & 622 \\
\hline
\end{tabular}

Beginning with the 1999 CBECS, EIA began identifying service type buildings, which previously had been included in the Retail" category. Figure 4.1 shows the resulting decrease in retail buildings and the concomitant appearance of buildings in the service category.

\footnotetext{
$\S$ The International Code Council also publishes a plumbing code, the International Plumbing Code (IPC). The IPC provides a more general gradation in minimum numbers of toilet fixtures than does the UPC. In addition, the IPC does not explicitly designate minimum numbers of urinals. For consistency, we use the UPC.
} 


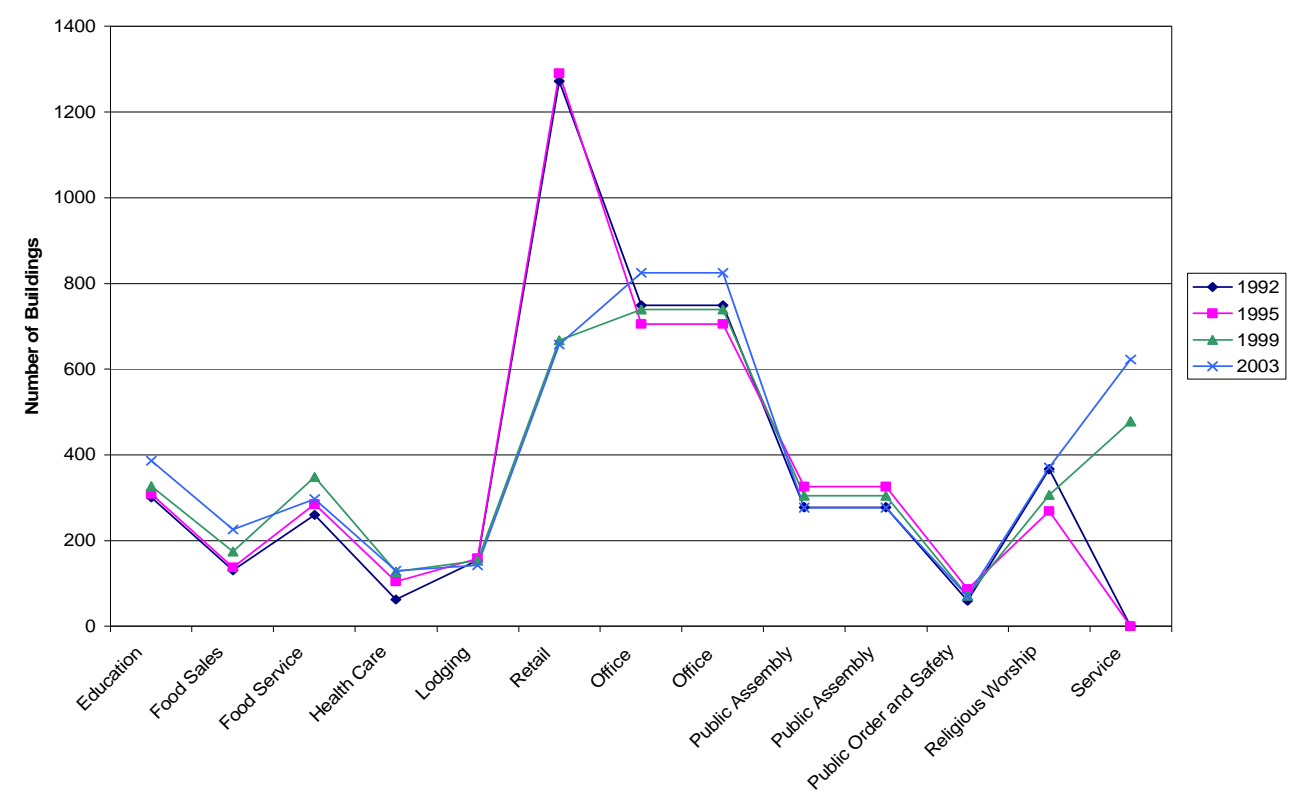

Figure 4.1 Numbers of Buildings by Type and CBECS Year

To estimate the numbers of FV toilets in commercial and institutional buildings, we used industry information regarding shipments and imports of toilets (Table 4.2).

Table 4.2 U.S. Shipments and Imports of Toilets (Catalina Research, 2007)

\begin{tabular}{|c|c|}
\hline Year & Toilets (000s) \\
\hline 1992 & 1,728 \\
\hline 1997 & 1,888 \\
\hline 2002 & 1,923 \\
\hline 2005 & 2,400 \\
\hline 2006 & 2,622 \\
\hline 2007 & 3,046 \\
\hline 2012 & 3,732 \\
\hline
\end{tabular}

Flushometer valve toilets do not represent 100 percent of the total estimated number of toilets in the commercial/institutional (CI) sector nationwide. Depending on the type of structure and the numbers and needs of employees and visitors, the toilets installed in nonresidential buildings may be gravity flush, pressure-assisted, or FV. FV toilets are noisier than gravity-flush toilets and generally are offered in only one color, so are not appropriate for all CI installations. In 
addition, FV toilets require at least 14 inches of interior wall space for piping, a 1-inch water supply line, and a water pressure of 10 to 100 pounds per square inch (http://www.plumbingsupply.com/sloan-flushometer-parts.html). Table 4.3 shows the percentages of each type of toilet various studies have estimated for CI applications.

Table 4.3 Percentages of Various Toilet Types

\begin{tabular}{|l|c|c|c|c|}
\hline \multicolumn{1}{|c|}{ Source } & $\begin{array}{c}\text { No. of } \\
\text { Toilets }\end{array}$ & $\begin{array}{c}\text { Gravity } \\
\text { Flush }\end{array}$ & $\begin{array}{c}\text { Pressure- } \\
\text { Assisted }\end{array}$ & $\begin{array}{c}\text { Flushometer } \\
\text { Valve }\end{array}$ \\
\hline $\begin{array}{l}\text { Santa Clara Valley Water } \\
\text { District (SCVWD), 2008 }\end{array}$ & 757 & $54.7 \%$ & $12.3 \%$ & $33 \%$ \\
\hline $\begin{array}{l}\text { Allinson, 2009 (Plumbing } \\
\text { Engineer magazine) }\end{array}$ & & & $80 \%$ \\
\hline $\begin{array}{l}\text { McLeod, 2009 (Redlon \& } \\
\text { Johnson) }\end{array}$ & 4 mil. & $50 \%$ & & $80 \%$ \\
\hline Koeller \& Co., 2005 & & & \\
\hline
\end{tabular}

Three sources find that FV toilets represent between 33 percent and 80 percent of all toilets in CI installations (Allinson, 2009; McLeod, 2009; SCVWD, 2008). Averaging the minimum and maximum estimates for FV toilets in nonresidential buildings yields a value of 55 percent plus or minus 25 percent.

\subsubsection{Urinals}

To determine the total number of urinals per person in CI buildings, we again referred to the IAMPO's UPC. ${ }^{* *}$ The UPC stipulates the minimum number of urinals required in a nonresidential building as a function of the number of male employees and visitors.

Information in the EIA's CBECS helped us estimate the number of people per building and building type. Industry data reported historical shipments of urinals (Table 4.4).

\footnotetext{
** As noted for FV toilets, the International Code Council also publishes a plumbing code, the International Plumbing Code (IPC). The IPC provides a more general gradation in minimum numbers of toilet fixtures than does the UPC. In addition, the IPC does not explicitly designate minimum numbers of urinals. Because the IAPMO's UPC provides greater specificity regarding urinals in different building types, we relied on the UPC to develop model inputs.
} 
Table 4.4 U.S. Shipments and Imports of Urinals (Catalina Research, 2007)

\begin{tabular}{|c|c|}
\hline Year & Urinals (000s) \\
\hline 1987 & 247 \\
\hline 1992 & 233 \\
\hline 1997 & 303 \\
\hline 2002 & 346 \\
\hline 2006 & 343 \\
\hline 2007 & 348 \\
\hline 2012 & 371 \\
\hline
\end{tabular}

\subsubsection{Pre-Rinse Spray Valves}

Pre-rinse spray valves are used in commercial and institutional settings to pre-wash plates, utensils, and cookware before they are placed in a dishwasher. To estimate the number of prerinse spray valves in use, we first assumed that all food service establishments have at least one pre-rinse spray valve. ${ }^{\dagger \dagger}$ As reported in a study of water use in the commercial, institutional, and industrial sectors in California [Santa Clara Valley Water District (SCVWD), 2008], other nonresidential enterprises also use them (Table 4.5). According to the SCVWD study, half of educational buildings, more than half of hospitals, and almost two-thirds of lodging facilities have pre-rinse spray valves. Table 4.5 shows the estimated total of 625,000 pre-rinse spray valves nationwide broken down by building type.

Table 4.5 Pre-Rinse Spray Valves by Building Type

\begin{tabular}{|l|c|c|c|c|}
\hline $\begin{array}{c}\text { Building } \\
\text { Type }\end{array}$ & $\begin{array}{c}\text { No. in } \\
\text { Sample }^{1}\end{array}$ & $\begin{array}{c}\text { Presence of } \\
\text { Spray Valve } \\
(\%))^{1}\end{array}$ & $\begin{array}{c}\text { No. of } \\
\text { Buildings } \\
(\mathbf{0 0 0 s})^{2}\end{array}$ & $\begin{array}{c}\text { No. of Pre-Rinse } \\
\text { Spray Valves } \\
(\mathbf{0 0 0 s})\end{array}$ \\
\hline Food Service & & 100 & 297 & 297 \\
\hline Education & 22 & 50 & 386 & 193 \\
\hline Health Care & 22 & 5 & 121 & 6 \\
\hline Hospital & 5 & 60 & 8 & 5 \\
\hline Lodging & 22 & 64 & 142 & 91 \\
\hline Office & 26 & 4 & 824 & 33 \\
\hline \multicolumn{2}{|r}{} & & Total & 625 \\
\hline
\end{tabular}

${ }^{1}$ SCVWD, 2008.

${ }^{2}$ EIA, 2003 CBECS.

\footnotetext{
${ }^{\dagger}$ Personal communication with Don Fisher, Food Service Technology Center, May 1, 2009.
} 


\subsection{Frequency or Duration of Use}

The mere presence of a water-using product does not mean that water is consumed. Water consumption reflects not only the quantity of products in use, but also their frequency or duration of use. For FV toilets and urinals, frequency of use is measured by numbers of flushes. For prerinse spray valves, duration of use is measured by the length of time the valve is open.

We estimated the frequency or duration of use of the three water-using products in CI settings as a function of parameters that include:

- type of building,

- number of workdays,

- number of hours worked per week and length of work day,

- number of employees (or residents if dormitory or residential care facility), and

- number of visitors or customers.

Table 4.6 quantifies the above parameters by building type. One California study (Pacific Institute, 2003) assumed 225 workdays per year for buildings in the Office, Public Assembly, Public Order and Safety, Religious Worship, and Service categories. For Schools, workdays per year were assumed to be 180. Restaurants, Retail, Hospitals, and Lodging were assumed to function every day of the year. Average workdays were 8 hours for office-type buildings and 6 hours for schools. Lacking published data, the study assumed that each employee has one visitor per day. Based on a 1992 Metropolitan Water District report (described in Appendix E of Pacific Institute, 2003b), 50 percent of visitors use the restroom. A later study found that of that 50 percent, two-thirds use toilets and one-third use urinals [Water Management, Inc. (WMI), et al., 2007]. 
Table 4.6 Parameters for Frequency of Use by Building Type

\begin{tabular}{|l|c|c|c|c|}
\hline \multicolumn{1}{|c|}{ Building Type } & $\begin{array}{c}\text { No. of } \\
\text { Buildings } \\
(\mathbf{0 0 0 s})\end{array}$ & $\begin{array}{c}\text { No. of } \\
\text { Employees } \\
(\mathbf{0 0 0 s})^{1}\end{array}$ & $\begin{array}{c}\text { No. of } \\
\text { Workdays }\end{array}$ & $\begin{array}{c}\text { Length of } \\
\text { Workday } \\
\text { (hours) }\end{array}$ \\
\hline Education & 386 & 12,489 & 180 & 6 \\
\hline Food Sales & 226 & 1,430 & 365 & 8 \\
\hline Food Service & 297 & 3,129 & 365 & 8 \\
\hline Health Care & 129 & 6,317 & 365 & 8 \\
\hline Lodging & 142 & 2,457 & 365 & 8 \\
\hline Retail (other than Mall) & 443 & 3,463 & 365 & 8 \\
\hline Office & 824 & 28,154 & 225 & 8 \\
\hline Public Assembly & 277 & 2,396 & 225 & 8 \\
\hline Public Order and Safety & 71 & 1,347 & 225 & 8 \\
\hline Religious Worship & 370 & 1,706 & 225 & 8 \\
\hline Service & 622 & 3,667 & 225 & 8 \\
\hline
\end{tabular}

${ }^{1}$ EIA, 2003 CBECS.

${ }^{2}$ Pacific Institute, 2003b.

\subsubsection{Flushometer Valve Toilets}

A major California study estimated the frequency of toilet use in six categories of nonresidential buildings (Pacific Institute, 2003a). Another study examined the frequency of water and toilet use in a university setting (WMI et al., 2007). Depending on the category, estimates ranged from two to four toilet flushes per day per employee (Table 4.7). 
Table 4.7 Frequency of Toilet Flushing in Nonresidential Settings

\begin{tabular}{|c|c|c|c|c|c|}
\hline \multirow[b]{2}{*}{$\begin{array}{c}\text { Building } \\
\text { Type }\end{array}$} & \multicolumn{2}{|c|}{$\begin{array}{c}\text { Toilet Flush } \\
\text { Frequency (per } \\
\text { employee or } \\
\text { resident/day) }\end{array}$} & \multirow[t]{2}{*}{$\begin{array}{l}\text { Toilet Flush Frequency } \\
\text { with Urinal Present } \\
\text { (per employee or } \\
\text { resident/day) }\end{array}$} & \multicolumn{2}{|c|}{$\begin{array}{c}\text { Toilet Flush } \\
\text { Frequency (per } \\
\text { visitor or } \\
\text { customer/day) }\end{array}$} \\
\hline & $\begin{array}{l}\text { WMI et } \\
\text { al., } 2007\end{array}$ & $\begin{array}{c}\text { Pacific } \\
\text { Institute, } \\
2003 \\
\end{array}$ & & $\begin{array}{l}\text { Pacific } \\
\text { Institute, } \\
2003\end{array}$ & $\begin{array}{l}\text { WMI et } \\
\text { al., } 2007\end{array}$ \\
\hline Education & 4.8 & 1.95 & 3.8 & 0.86 & 1 \\
\hline Food Sales & & & & 0.34 & \\
\hline Food Service & & 2.6 & & & \\
\hline Health Care & & 2.6 & & 1 & \\
\hline Lodging & & 2.6 & & & \\
\hline Retail & & 2.6 & & 0.13 & \\
\hline Office & & 2.6 & & 0.33 & \\
\hline
\end{tabular}

\subsubsection{Urinals}

A range of values are reported for frequency of urinal flushing (Table 4.8). One study notes generally two flushes per employee per day (Konen, cited in Bamezai and Chestnutt, 1994). Another source estimates three to five flushes per employee per day (Dalby Regional Council). Three studies reported in Pacific Institute (2003b) note two to four flushes per employee per day, depending on the enterprise.

Table 4.8 Frequency of Urinal Flushing

\begin{tabular}{|l|c|}
\hline \multicolumn{1}{|c|}{ Source } & $\begin{array}{c}\text { Urinal Flush Frequency (per } \\
\text { employee or resident/day) }\end{array}$ \\
\hline $\begin{array}{l}\text { Dalby Regional Council, } \\
\text { Queensland, Australia }\end{array}$ & 3 to 5 \\
\hline $\begin{array}{l}\text { Konen in Bamezai and } \\
\text { Chestnutt, 1994 }\end{array}$ & 2 \\
\hline Pacific Institute, 2003b & 2 to 4 \\
\hline
\end{tabular}

The California study (Pacific Institute, 2003b) assumed that each male student other than those in kindergarten through $12^{\text {th }}$ grade uses a urinal 0.31 times per day, and each male school staff member uses one 0.94 times per day. For office settings, we averaged two estimates of the number of times employees in office buildings use toilet facilities daily (see Table 4.7), then divided by two (because only men, presumably 50 percent of employees, use urinals). Table 4.9 shows the results for frequency of urinal flushing in various building types. 
Table 4.9 Frequency of Urinal Flushing in Nonresidential Settings

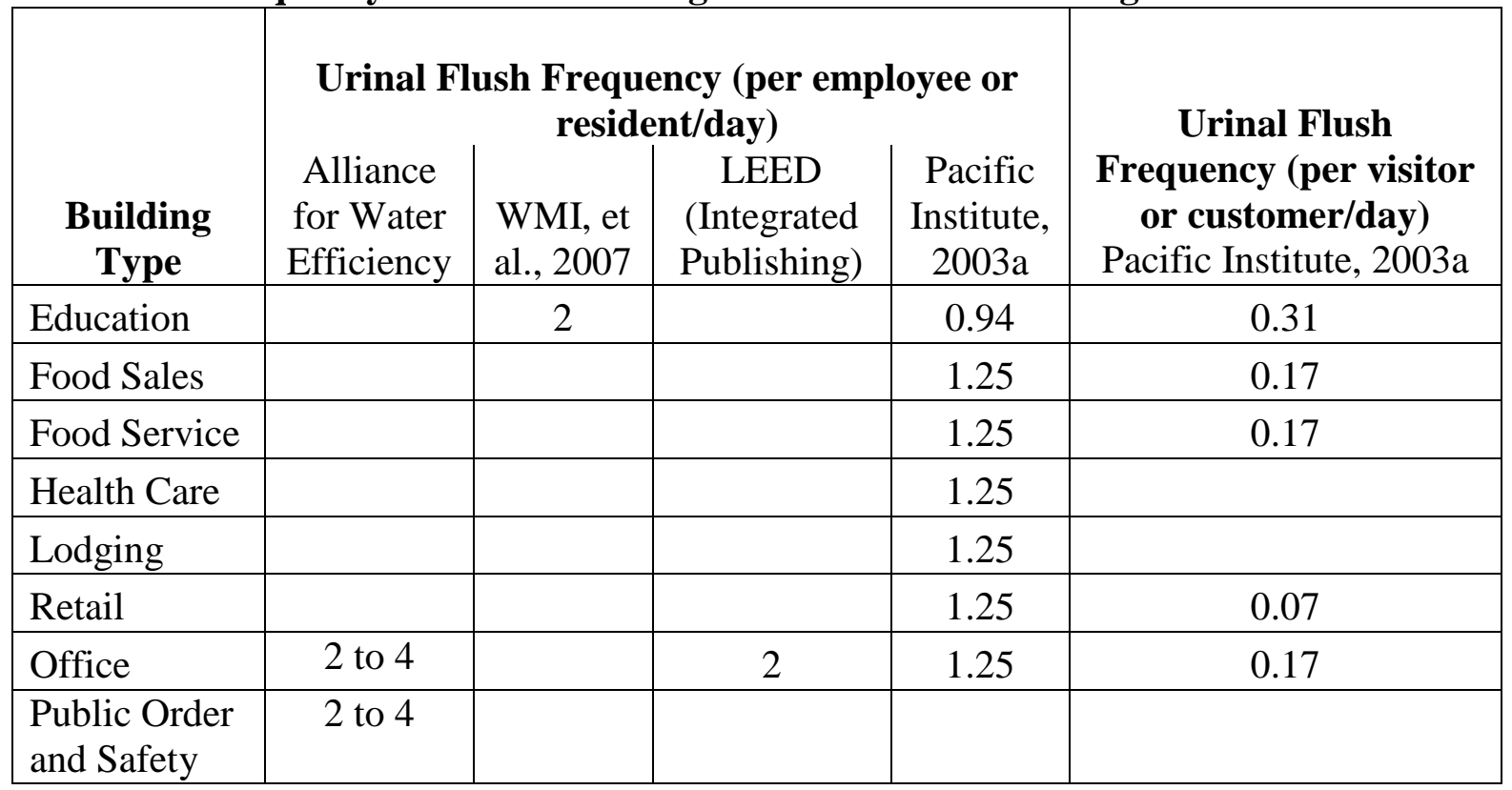

\subsubsection{Pre-rinse Spray Valves}

In a restaurant settings, pre-rinse spray valves are used routinely to rinse dishes, utensils, and cookware before they are machine-washed. Estimates of the number of restaurants in the United States range from 300,000 (EIA, CBECS 2003) to 945,000 (National Restaurant Association, 2009). We conservatively assume that each restaurant has one pre-rinse spray valve. Pre-rinse spray valves can account for as much as 35 percent of kitchen water use (WMI et al., 2007; Koeller and Dickinson, 2003). These latter two studies report that spray valve use in restaurants ranges from more than three-quarters of an hour to more than two hours per day. The use of spray valves related to food sales in convenience or grocery stores is reported to be considerably less, less than one-quarter of an hour (Table 4.10). 
Table 4.10 Duration of Pre-Rinse Spray Valve Use (hours/day) in Nonresidential Settings

\begin{tabular}{|l|c|c|c|c|}
\hline \multicolumn{1}{|c|}{ Study } & \multicolumn{1}{|c|}{$\begin{array}{c}\text { General } \\
\text { Use }\end{array}$} & $\begin{array}{c}\text { Education and } \\
\text { Institutional }^{1}\end{array}$ & $\begin{array}{c}\text { Food } \\
\text { Service }\end{array}$ & Food Sales \\
\hline $\begin{array}{l}\text { Canadian Meter } \\
\text { Installation Services, } \\
\text { Inc., \& Veritec } \\
\text { Consulting, Inc. 2008 }\end{array}$ & $0.78-0.83$ & & & \\
\hline Green Workplace & 2 & & & \\
\hline WMI, 2007 & & 2.2 & & \\
\hline FEMP, 2004 & & 4 & & \\
\hline $\begin{array}{l}\text { SBW Consulting, } \\
\text { 2007 }\end{array}$ & & & $0.54-0.73$ & $0.08-0.10$ \\
\hline Tso and Koeller, 2005 & & & $0.79-1.02$ & $0.11-0.14$ \\
\hline
\end{tabular}

${ }^{1}$ Veterans' hospitals, federal prisons, and military bases.

\subsubsection{Hot Water Use}

Because pre-rinse spray valves use hot water, they consume both water and the energy required to heat that water. Depending on the area of the country, electricity or gas generally is used to heat water. The Food Service Technology Center (2009) reports a wide range in hot water use for food service establishments. Full-service restaurants can average 2,500 hot-water gallons per day. Fast-food outlets use about a fifth of that amount, averaging 500 hot-water gallons per day. Associated gas use is 8,800 therms per year for full-service restaurants and 1,400 therms per year for fast-food outlets

(http://www.fishnick.com/education/presentations/Energy_Efficient_Water_Heating_and_Delive ry_Mar-2009.pdf). SBW Consulting (2007) and Tso and Koeller (2005) report that the ratio of cold to hot water for pre-rinse spray valves ranged from 73 percent to 84 percent; restaurants and institutional cafeterias used warmer water than did grocery stores (Table 4.11).

The Federal Energy Management Program (FEMP) developed higher estimates of hourly hot water use. In establishing an upper bound based on an average pre-rinse spray valve use of 4 hours per day, 365 days per year, FEMP estimated annual gas consumption related to pre-rinse spray valves to be 842 therms to heat 140 thousand gallons of water, assuming a boiler efficiency of 80 percent and a $58^{\circ} \mathrm{F}$ rise in temperature (FEMP, 2008). 
Table 4.11 Water Temperatures for Pre-Rinse Spray Valves (Tso and Koeller, 2005; SBW Consulting, 2007)

\begin{tabular}{|l|c|c|c|}
\hline \multicolumn{1}{|c|}{ Building Type } & $\begin{array}{c}\text { Mixed Water } \\
\text { Temp. }\left({ }^{\circ} \mathbf{F}\right)\end{array}$ & $\begin{array}{c}\text { Hot Water } \\
\text { Temp. }\left({ }^{\circ} \mathbf{F}\right)\end{array}$ & $\begin{array}{c}\text { Percent of Hot to } \\
\text { Cold Water }(\%)\end{array}$ \\
\hline Restaurant & $97.6-107.0$ & $119.6-127.5$ & 82 \\
\hline $\begin{array}{l}\text { Food Sales } \\
\text { (Groceries) }\end{array}$ & $86.1-97.6$ & 118.5 & 73 \\
\hline Institutions & 91.4 & 109.1 & 84 \\
\hline Other & 89.5 & 114.7 & 78 \\
\hline
\end{tabular}

\subsection{Rates of Market Saturation}

The three products being evaluated for the WaterSense CI label serve one of two markets: new construction/remodeling or replacement of a failed unit. The market saturation of the three products depends on the natural replacement rate for failed products, the product lifetimes, and rates of new construction.

\subsubsection{Product Lifetimes}

Several studies have projected the lifetimes of the CI products being evaluated for the WaterSense labeling program. The lifetimes reported in those studies range from 30 years for flushometer valve toilets and urinals to 5 years for pre-rinse spray valves (Table 4.12).

Table 4.12 Lifetimes of Commercial Products (years) by Study

\begin{tabular}{|l|c|c|c|}
\hline \multicolumn{1}{|c|}{ Study } & $\begin{array}{c}\text { Flushometer } \\
\text { Valve Toilets }\end{array}$ & Urinals & $\begin{array}{c}\text { Pre-rinse } \\
\text { Spray Valves }\end{array}$ \\
\hline SCVWD, 2008 & 20 & 20 & 5 \\
\hline CEC, ${ }^{1}$ pre-2006 & & & 5 \\
\hline Koeller \& Co., 2005 & 30 & 30 & \\
\hline
\end{tabular}

${ }^{1}$ California Energy Commission.

\subsubsection{Product Replacement Rates}

The natural replacement rate for flushometer valve toilets and urinals is 4 percent annually (Sonoma County, no date). The average rate of new construction is 2 percent annually. We assume that installation rates for toilets and for urinals are identical. Because we lack information on the replacement rate for pre-rinse spray valves, we assign them a 5-percent replacement rate based on their shorter lifetime.

\footnotetext{
F From the CEC, pre-2006, and SWB Consulting, 2007, who assumed an average retention rate of 94.6 percent during the first year after an old unit was replaced with a high-efficiency spray valve.
} 


\subsubsection{Rate of New Construction}

Current turbulent economic conditions render forecasts of nonresidential construction starts uncertain at best. Figure 4.2 and Table 4.13 show forecasts of commercial floorspace, both surviving and in new construction, from the Energy Information Administration's (EIA's) Annual Energy Outlook (AEO) for 2009. Data for new space are read off the vertical axis on the right. Using 2006 as the base year, new construction shows a steady decline after 2008 and an almost 30-percent drop by 2011, after which it begins to increase. The EIA's AEO 2009 forecasts a softer downturn in 2018, after which construction returns to 2006 levels by 2029. A slowdown in new construction shifts the basis for demand of water-conserving products to product lifetime rather than a combination of product lifetime and new construction.

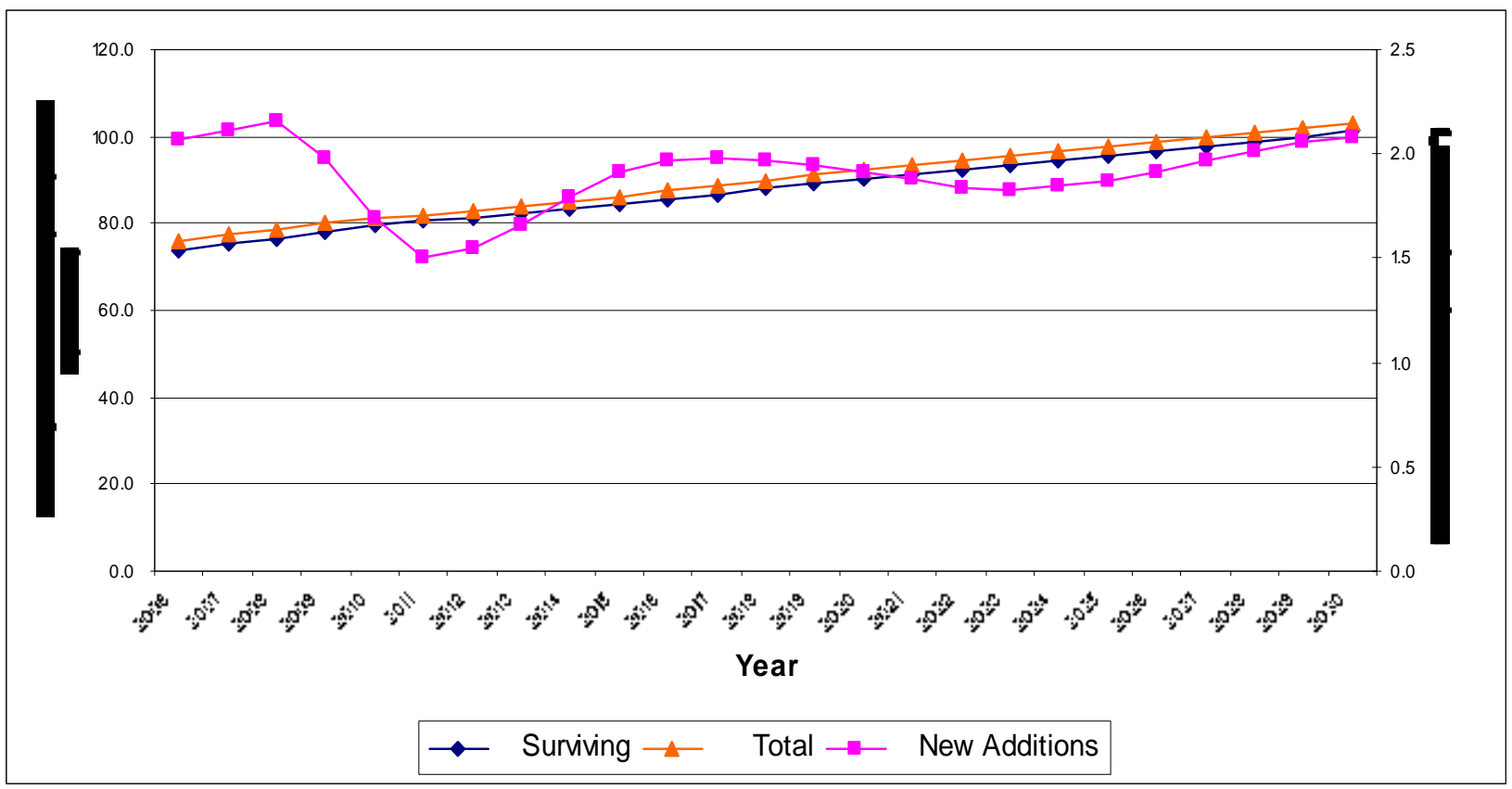

Figure 4.2 Forecast of Surviving and New Construction of Commercial Floorspace in the United States (EIA, 2009 AEO) 
Table 4.13 Forecast of Nonresidential Floorspace (billion square feet) (EIA, 2009 AEO)

\begin{tabular}{|c|c|c|c|}
\hline Year & Surviving & $\begin{array}{c}\text { New } \\
\text { Construction }\end{array}$ & Total \\
\hline 2006 & 73.7 & 2.1 & 75.8 \\
\hline 2007 & 75.2 & 2.1 & 77.3 \\
\hline 2008 & 76.6 & 2.2 & 78.8 \\
\hline 2009 & 78.1 & 2.0 & 80.1 \\
\hline 2010 & 79.5 & 1.7 & 81.2 \\
\hline 2011 & 80.5 & 1.5 & 82.0 \\
\hline 2012 & 81.3 & 1.5 & 82.9 \\
\hline 2013 & 82.2 & 1.7 & 83.8 \\
\hline 2014 & 83.1 & 1.8 & 84.9 \\
\hline 2015 & 84.2 & 1.9 & 86.1 \\
\hline 2016 & 85.4 & 2.0 & 87.4 \\
\hline 2017 & 86.7 & 2.0 & 88.6 \\
\hline 2018 & 87.9 & 2.0 & 89.9 \\
\hline 2019 & 89.1 & 1.9 & 91.1 \\
\hline 2020 & 90.3 & 1.9 & 92.2 \\
\hline 2021 & 91.4 & 1.9 & 93.3 \\
\hline 2022 & 92.5 & 1.8 & 94.4 \\
\hline 2023 & 93.6 & 1.8 & 95.4 \\
\hline 2024 & 94.6 & 1.8 & 96.4 \\
\hline 2025 & 95.6 & 1.9 & 97.5 \\
\hline 2026 & 96.7 & 1.9 & 98.6 \\
\hline 2027 & 97.7 & 2.0 & 99.7 \\
\hline 2028 & 98.9 & 2.0 & 100.9 \\
\hline 2029 & 100.0 & 2.1 & 102.1 \\
\hline 2030 & 101.2 & 2.1 & 103.3 \\
\hline
\end{tabular}

In addition to nonresidential construction starts, employment statistics also affect estimates of water savings from WaterSense products, because the mere presence of water-using products does not compel water consumption. The United States Department of Labor's Bureau of Labor Statistics (BLS) forecasts employment trends for all occupations combined and individually. Table 4.14 shows the BLS employment forecasts through 2016 for BLS employment codes and categories (U.S. BLS, 2007). Except for the categories of farming, fisheries, forestry, and production, all major job classifications show increases, indicating that use of commercial waterusing products will increase. 
Table 4.14 Recent and Predicted National Employment (U.S. BLS, 2007)

\begin{tabular}{|c|c|c|c|c|c|c|c|}
\hline \multirow[b]{2}{*}{ Occupation } & \multirow{2}{*}{$\begin{array}{l}\text { BLS } \\
\text { Code }\end{array}$} & Numbe & $(000 s)$ & $\begin{array}{l}\text { ent } \\
\text { Pe } \\
\text { Distr }\end{array}$ & $\begin{array}{l}\text { ent } \\
\text { ution }\end{array}$ & Ch & ge \\
\hline & & 2006 & 2016 & 2006 & 2016 & $(000 s)$ & Percent \\
\hline Total, all occupations & $\begin{array}{l}00- \\
0000\end{array}$ & 150,620 & 166,220 & 100 & 100 & $+15,600$ & +10.4 \\
\hline $\begin{array}{l}\text { Management, business, } \\
\text { and financial }{ }^{(1)}\end{array}$ & $\begin{array}{l}11- \\
1300\end{array}$ & 15,397 & 16,993 & 10.2 & 10.2 & $+1,596$ & +10.4 \\
\hline Professional and related ${ }^{(2)}$ & $\begin{array}{l}15- \\
2900\end{array}$ & 29,819 & 34,790 & 19.8 & 20.9 & $+4,970$ & +16.7 \\
\hline Service $^{(3)}$ & $\begin{array}{l}31- \\
3900\end{array}$ & 28,950 & 33,780 & 19.2 & 20.3 & $+4,830$ & +16.7 \\
\hline Sales and related & $\begin{array}{l}41- \\
0000\end{array}$ & 15,985 & 17,203 & 10.6 & 10.3 & $+1,218$ & +7.6 \\
\hline $\begin{array}{l}\text { Office and administrative } \\
\text { support }\end{array}$ & $\begin{array}{l}43- \\
0000\end{array}$ & 24,344 & 26,089 & 16.2 & 15.7 & $+1,745$ & +7.2 \\
\hline $\begin{array}{l}\text { Farming, fishing, and } \\
\text { forestry }\end{array}$ & $\begin{array}{l}45- \\
0000\end{array}$ & 1,039 & 1,010 & 0.7 & 0.6 & -29 & -2.8 \\
\hline $\begin{array}{l}\text { Construction and mineral } \\
\text { extraction }\end{array}$ & $\begin{array}{l}47- \\
0000\end{array}$ & 8,295 & 9,079 & 5.5 & 5.5 & +785 & +9.5 \\
\hline $\begin{array}{l}\text { Installation, maintenance, } \\
\text { and repair }\end{array}$ & $\begin{array}{l}49- \\
0000\end{array}$ & 5,883 & 6,433 & 3.9 & 3.9 & +550 & +9.3 \\
\hline $\begin{array}{l}\text { Production and } \\
\text { manufacturing }\end{array}$ & $\begin{array}{l}51- \\
0000\end{array}$ & 10,675 & 10,147 & 7.1 & 6.1 & -528 & -4.9 \\
\hline $\begin{array}{l}\text { Transportation and } \\
\text { material moving }\end{array}$ & $\begin{array}{l}53- \\
0000 \\
\end{array}$ & 10,233 & 10,695 & 6.8 & 6.4 & +462 & +4.5 \\
\hline
\end{tabular}

${ }^{1}$ Major occupational groups 11-0000 through 13-0000 in the 2000 Standard Occupational Classification (SOC).

${ }^{2}$ Major occupational groups 15-0000 through 29-0000 in the 2000 SOC.

${ }^{3}$ Major occupational groups 31-0000 through 39-0000 in the 2000 SOC.

\section{SUMMARY OF CALCULATED INPUTS}

Table 5.1 outlines the inputs LBNL developed for the National Water Savings model for commercial and institutional products (NWS-CI). Table 5.1 summarizes information regarding the frequency or duration of use; the savings between the standard and the WaterSense flow rate; and the rate of replacement based on projected product lifetimes of flushometer valve toilets, urinals, and pre-rinse spray valves. In developing the inputs we indirectly utilized data regarding square footage of commercial/institutional buildings, plumbing codes, and employment rates, among others. 
Table 5.1 Summary of Data Used as Inputs to Model

\begin{tabular}{|l|c|c|c|c|}
\hline \multicolumn{1}{|c|}{ Product } & $\begin{array}{c}\text { Frequency of } \\
\text { Use }\end{array}$ & $\begin{array}{c}\text { Savings per Unit } \\
\mathbf{( 1 9 9 4 \text { Standard- }} \\
\text { WaterSense Target) }\end{array}$ & $\begin{array}{c}\text { Annual } \\
\text { Replacement } \\
\text { Rate (\%) }\end{array}$ & $\begin{array}{c}\text { Life- } \\
\text { time } \\
\text { (years) }\end{array}$ \\
\hline $\begin{array}{l}\text { Flushometer } \\
\text { Valve Toilet }\end{array}$ & $\begin{array}{c}3 \text { flushes per } \\
\text { employee per day }\end{array}$ & $\begin{array}{c}1.6-1.28=0.32 \\
\text { gallon per flush }\end{array}$ & 4 & 25 \\
\hline Urinal & $\begin{array}{c}3 \text { flushes per male } \\
\text { employee per day }\end{array}$ & $\begin{array}{c}1-0.5=0.5 \text { gallon } \\
\text { per flush }\end{array}$ & 4 & 25 \\
\hline $\begin{array}{l}\text { Pre-Rinse } \\
\text { Spray Valve }\end{array}$ & 2 hours per day & $\begin{array}{c}1.6-1.28=0.32 \\
\text { gallon per minute }\end{array}$ & 5 & 5 \\
\hline
\end{tabular}

\section{BIBLIOGRAPHY}

Alliance for Water Efficiency's Resource Library, Commercial, Institutional, and Industrial Water Users.

http://www.allianceforwaterefficiency.org/Commercial_Institutional_and_Industrial_Librar y_Content_Listing.aspx.

Alliance for Water Efficiency. No Date. Government buildings and public facilities. http://www.allianceforwaterefficiency.org/government.aspx.

Allinson, Timothy. Plumbing designer columnist, Plumbing Engineer. Personal communication with Camilla Dunham Whitehead. March 31, 2009.

Bamezai, A., and Chestnutt, T.W. 1994. Water Savings from Non-Residential Toilet Retrofits: An Evaluation of the City of San Diego's Public Facilities Retrofit Program. Submitted to the Metropolitan Water District of Southern California by A\&N Technical Services, Inc. December.

California Energy Commission (CEC). Pre-2006. CEC Commercial Kitchens Initiative. Program Guidance on Pre-Rinse Spray Valves. http://www.cee1.org/com/com-kit/prv-guides.pdf. 4 p.

California Urban Water Conservation Council (CUWCC). 2008. Best Management Practice (BMP) 9. http://www.cuwcc.org/mou/exhibit-1-bmp-definitions-schedulesrequirements.aspx. Last updated December 10. Last accessed March 12, 2009.

CUWCC's Resource Center. http://www.cuwcc.org/resource-center/resource-center.aspx. 
Canadian Meter Installation Services, Inc., and Veritec Consulting, Inc. 2008. City of Calgary Pre-Rinse Spray Valve Replacement Program: Final Report.

http://www.calgary.ca/docgallery/bu/water_services/conservation/indoor/calgary_pre_rins e_report.pdf. June. 27 p.

Chicago Faucets. 2005. Schematic of pre-rinse spray valve. http://www.chicagofaucet.com/CompleteDrawings/pdf/RI510-GCLCP.pdf.

Dalby Regional Council. No date. Method for calculating water savings from more efficient urinals. Support for applications for Business Water Efficiency Program funds. Dalby Regional Council, Queensland, Australia. Last accessed March 13, 2009. http://www.dalbyrc.qld.gov.au/services/documents/water/urinal_savings.pdf

Energy Information Administration (EIA). Annual Energy Outlook (AEO) for 2003. U.S. Department of Energy. http://www.eia.doe.gov/emeu/cbecs/cbecs2003/detailed_tables_2003/2003set1/2003pdf/b1. pdf. Last accessed March 12, 2009.

EIA. Annual Energy Outlook for 2009. U.S. Department of Energy. Report \# DOE/EIA0383(2009), early release. http://www.eia.doe.gov/oiaf/aeo/excel/aeotab_5.xls. Last accessed March 11, 2009.

EIA. 1992, 1995, 1999, and 2003. Commercial and Business Energy Consumption Survey (CBECS). U.S. Department of Energy, Energy Information Administration.

Federal Energy Management Program (FEMP). 2008. How to buy a low-flow pre-rinse spray valve. U.S. Department of Energy, Energy Efficiency and Renewable Energy, Federal Energy Management Program. December. http://www1.eere.energy.gov/femp/procurement/eep_low-flow_valves.html. Last accessed March 19, 2009.

Fisher, Don. Food Service Technology Center. 2009. Personal communication with Camilla Dunham Whitehead. May 1.

Food Service Technology Center. 2009. Energy Efficient Water Heating \& Distribution for Commercial Foodservice. Fisher-Nickel, Inc.; Pacific Gas and Electric Company. 
http://www.fishnick.com/education/presentations/Energy_Efficient_Water_Heating_and_D elivery_Mar-2009.pdf. March 5. 50 p. Last accessed March 19, 2009.

Green Workplace. No date. Executive summary on Web page describes program to install efficient pre-rinse spray valves in food-service establishments and institutional kitchens. The program, which ran from July to October 2007, comprised a total of 730 pre-rinse spray valves. http://www.greenworkplace.ca/Large\%20outsourcing\%20report.pdf. 8 p.

HydroEnhanced Laboratories, Inc. 1998. Water conservation case study for Munroe Regional Medical Center, Ocala, FL. Clarion Capital Corporation, the Energy Centre, Winter Haven, FL.

http://www.conservacap.com/Project\%20Succusses/Munroe_Regional_Medical_Center.ht m. Last accessed March 10, 2009.

Integrated Publishing. Government Services Administration, Leadership in Energy and Environmental Design (LEED) Cost Study. Tables WE3.1-1 and WE3.2 report baseline water use and reductions in water use from low-flow faucets and urinals in an office building. http://www.tpub.com/content/gsacriteria/gsaleed/index.htm. Last accessed March $12,2009$.

International Association of Plumbing and Mechanical Officials (IAMPO). 2009. Uniform Plumbing Code (UPC). IAMPO, 5001 E. Philadelphia St., Ontario, CA 91761.

International Code Council (ICC). 2009. International Plumbing Code (IPC). ICC, Washington, D.C. 20001.

Koeller \& Co. 2005. Potential Best Management Practices-High-Efficiency Urinals (HEUs) and High-Efficiency Toilets (HETs). Prepared for the California Urban Water Conservation Council by Koeller \& Company. November 1.

Koeller \& Co. 2009. High Efficiency Urinals (HEUs), U.S. and Canada. From the CUWCC website: http://www.cuwcc.org/WorkArea/showcontent.aspx?id=11446. Last accessed March 6, 2009.

Koeller, J., and Dickinson, M.A. 2003. Achieving energy and water savings in food service operations: the pre-rinse spray valve replacement program. June. Abstract obtained from 
WATERNET, the online index of publications of the American Water Works Association (AWWA) and the AWWA Research Foundation.

Koeller, J., and Mitchell, D. 2002. Commercial dishwashers: a new frontier in energy and water conservation. 2002 Water Sources Conference Proceedings. Abstract accessed via WATERNET, the online index of publications of the American Water Works Association (AWWA) and the AWWA Research Foundation

McLeod, Jim. Commercial plumbing designer, Redlon \& Johnson Plumbing Supply. Personal communication with Camilla Dunham Whitehead. March 31, 2009.

National Restaurant Association. 2009. 2009 Restaurant Industry Pocket Factbook. National Restaurant Association. Washington, D.C. 20036.

Pacific Institute. 2003a. Waste Not, Want Not: The Potential for Urban Water Conservation in California. Gleick, P.H., et al. Pacific Institute. Oakland, CA. November 13.

Pacific Institute. 2003b. Appendix E: Details of commercial water use and potential savings by sector. In Waste Not, Want: The Potential for Urban Water Conservation in California. Gleick, P.H., et al. Pacific Institute. Oakland, CA. November 13. http://www.pacinst.org/reports/urban_usage/appendix_e.pdf. Last accessed April 11, 2009. $22 \mathrm{p}$.

Plumbing Supply.com. Internet plumbing supplier. http://www.plumbingsupply.com/sloanflushometer-parts.html. Last accessed March 10, 2009.

Santa Clara Valley Water District. 2008. Commercial, Institutional, and Industrial (CII) Water Use and Conservation Baseline Study: Final Report. Water Use Efficiency Unit, Santa Clara Valley Water District, with CDM, Carbondale, IL, and Walnut Creek, CA. February. $210 \mathrm{p}$. http://www.valleywater.org/conservation/media/Documents/CII\%20Baseline\%20Study_C OMPLETE.pdf

Santa Cruz County. No date. Water conservation devices: what to know before you go low-flow. http://sccounty01.co.santacruz.ca.us/eh/Water_Resources/WhattoKnowBeforeYouGoLow-Flow.pdf. 
SBW Consulting. 2007. CUWCC Pre-Rinse Spray Head Distribution Program, Phase 2.

February. Prepared for California Urban Water Conservation Council by SBW Consulting, Inc., Bellevue, WA.

Schlunke, A., Lewis, J., and Fane, S. 2008. Analysis of Australian opportunities for more efficient toilets. Prepared for the Australian Government, Department of the Environment, Water, Heritage and the Arts, Institute for Sustainable Futures, University of Technology. Sydney. February. http://www.waterrating.gov.au/publications/pubs/water-efficienttoilets.pdf. 27 p.

Sonoma County. No date. "Exhibit \#29: Descriptions of the 14 best management practices." http://www.sonomacountywater.org/_pdf/swcrb_report/exhibits_29_35.pdf. Last accessed March 11, 2009.

Toto-Kiki Installation Manual. U.S. head office, TOTO USA, INC., 1155 Southern Road, Morrow, GA 30260. Tel: (770) 282-8686, Fax: (770) 282-0002.

Tso, B., and Koeller, J. 2005. Pre-rinse spray valve programs: how are they really doing? SBW Consulting/Koeller \& Co. December 1.

United Energy Associates, Inc. 2001. A water conversion case study: BellSouth Office Tower, Atlanta, GA.

http://www.uea.com/Case_Studies/Water_Management/Bellsouth_Atlanta.htm. Last accessed March 10, 2009.

United States Department of Labor, Bureau of Labor Statistics (BLS). 2007. Table 1, Employment by major occupational group, 2006 and projected 2016. In Occupational employment projections to 2016, published in the 2007 Monthly Labor Review. November. http://www.bls.gov/emp/emptab1.htm. Last accessed April 12, 2009.

United States Environmental Protection Agency. 2000. Wastewater technology fact sheet: high efficiency toilets. EPA 832-F-00-047. September.

Veritec Consulting, Inc. 2005. City of Calgary: Pre-Rinse Spray Valve Pilot Study. December.

Veritec Consulting, Inc. 2005. Region of Waterloo: Pre-Rinse Spray Valve Pilot Study: Final Report. January. 
Vickers, A. 2001. Handbook of Water Use and Conservation. WaterPlow Press. Amherst, MA.

Water Management, Inc., Amy Vickers \& Associates, Inc., and Resource Wise. 2007. Water Conservation Opportunities, UCONN (University of Connecticut). http://www.fo.uconn.edu/Dec\%2007\%20Wtr\%20Plan.pdf.

Whitcomb, J.B., et al. 2001. The CII/ULFT [Commercial, Industrial, and Institutional Ultra LowFlow Toilet] Savings Study, $2^{\text {nd }}$ edition. California Urban Water Conservation Council, Sacramento CA 95814. 